\title{
Ostre zapalenie osierdzia u chorego z tyreotoksykozą
}

\author{
Acute pericarditis in patient presenting with thyrotoxicosis
}

\author{
Gabriela Parol \\ I Katedra i Klinika Kardiologii Warszawskiego Uniwersytetu Medycznego
}

\section{Streszczenie}

Częstymi przyczynami ostrego zapalenia osierdzia są choroby z autoagresji. Powikłania ze strony układu sercowo-naczyniowego nierzadko dotyczą pacjentów z dysfunkcją tarczycy. Objawy związane z zastoinową niewydolnością serca, tachyarytmiami przedsionkowymi, zaburzeniami przewodzenia przedsionkowo-komorowego czy dysfunkcją zastawki dwudzielnej w przebiegu chorób tarczycy są dobrze znane klinicystom. Zapalenie osierdzia występuje rzadko w przebiegu zaburzeń funkcji tarczycy. Najczęściej dotyczy chorych z niedoczynnością tarczycy. Bardzo rzadko może być także sercową manifestacją choroby Graves-Basedowa.

Słowa kluczowe: zapalenie osierdzia, tyreotoksykoza

Folia Cardiologica 2016; 11, 2: 162-166

\section{Opis przypadku}

Trzydziestosześcioletni mężczyzna pochodzenia azjatyckiego został przyjęty do I Kliniki Kardiologii Warszawskiego Uniwersytetu Medycznego z powodu trwających od kilku godzin bólów w klatce piersiowej, nasilających się przy zmianie pozycji ciała i ruchach oddechowych. Pacjent niepalący, negował objawy infekcji, dotychczas nie był przewlekle leczony, podawał dodatni wywiad rodzinny w kierunku chorób układu sercowo-naczyniowego. W badaniu przedmiotowym przy przyjęciu pacjent był w stanie ogólnym średnim, zgłaszał ból w klatce piersiowej, hiperwentylował się. Ciśnienie tętnicze (BP, blood pressure) wynosiło 170/100 mm Hg; zwracały uwagę tachykardia 100/min i tachypnoe około 30/ /min. Osłuchowo nad polami płucnymi stwierdzono szmer pęcherzykowy prawidłowy, bez szmerów nad sercem, brzuch w badaniu przedmiotowym bez nieprawidłowości, bez obrzęków obwodowych. W badaniu elektrokardiograficznym (EKG) ujawniono tachykardię zatokową, obniżenie odcinka PR w odprowadzeniach II, III, aVF, uniesienie odcinka ST z wysokim odejściem punktu J w odprowadzeniach II, III, aVF i V3-V6 (ryc. 1). W badaniach laboratoryjnych przy przyjęciu nie stwierdzono podwyższonego stężenia markerów martwicy miokardium ani parametrów zapalnych. W badaniu echokardiograficznym stwierdzono nieznacznie pogrubiałe blaszki osierdzia, bez płynu w worku osierdziowym, hiperkinezę wszystkich segmentów lewej komory, bez innych nieprawidłowości. W kolejnym oznaczeniu bez podwyższenia stężenia markerów sercowych odnotowano podwyższone parametry zapalne oraz niewielkie podwyższenie stężenia N-końcowego propeptydu natriuretycznego typu B (NT-proBNP, N-terminal pro B-type natriuretic peptide). Na podstawie całości obrazu klinicznego wykluczono ostry zespół wieńcowy, rozpoznano natomiast ostre zapalenie osierdzia. Wdrożono do leczenia ibuprofen w dawce 3 razy $400 \mathrm{mg} /$ dobę oraz beta-adrenolityk ze względu na tachykardię (nebiwolol w dawce 2,5 mg/d.), uzyskując spadek parametrów zapalnych i zwolnienie czynności serca do około 70/min. W pierwszej dobie z powodu nasilonych dolegliwości bólowych podawano przejściowo dożylnie morfinę i paracetamol. W kontrolnych badaniach laboratoryjnych stwierdzono nieoznaczalne stężenia hormonu tyreotropowego (TSH, thyrotropin-stimulating hormone) oraz wolnej tyroksyny (fT4, free thyroxine), a także istotnie

Adres do korespondencji: lek. Gabriela Parol, I Katedra i Klinika Kardiologii, Warszawski Uniwersytet Medyczny, ul. Banacha 1A, 02-097 Warszawa, e-mail: gabriela.parol@wp.pl 


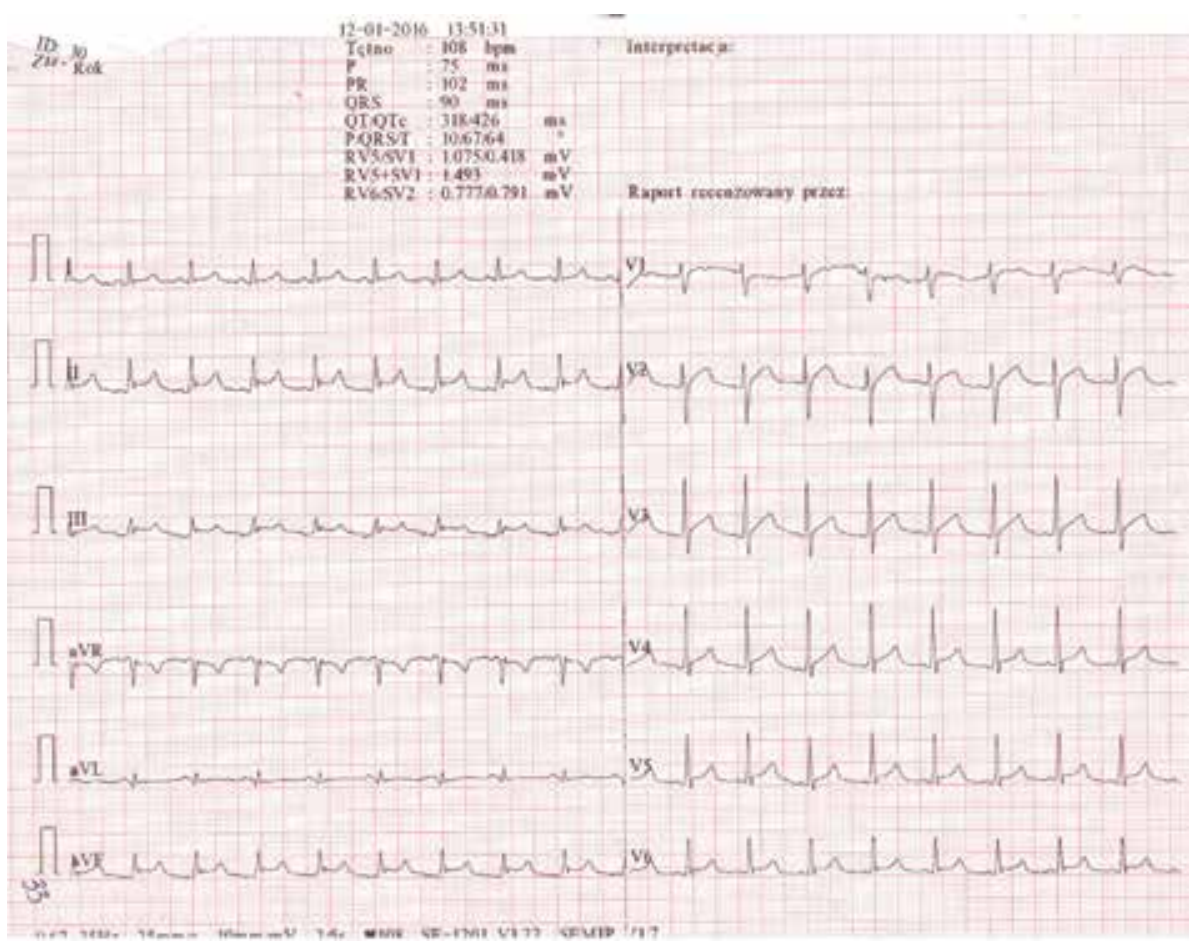

Rycina 1. Zapis elektrokardiograficzny pacjenta przy przyjęciu. Widoczne obniżenia odcinka PR w odprowadzeniach II, III i aVF oraz uniesienie odcinka ST w odprowadzeniach II, III, aVF i V3-V6

podwyższone stężenie wolnej trójjodotyroniny (fT3, free triiodothyronine), podwyższone miano przeciwciał przeciwko peroksydazie tarczycowej (ATPO, anti-thyroid peroxidase antibodies) oraz przeciwko receptorom dla TSH (anty-TSHr, TSH receptor antibodies) (tab. 1).

W badaniu ultrasonograficznym (USG) ujawniono powiększoną, częściowo schodzącą zamostkowo tarczycę, bez wzmożonego unaczynienia, o całkiem niejednorodnej echogeniczności miąższu. W kontrolnym badaniu echokardiograficznym stwierdzono pogrubiałe blaszki osierdzia i niewielką ilość płynu w worku osierdziowym, do 2-3 mm za ścianą dolno-boczną i boczną; w kontrolnym EKG w dniu wypisania - normalizacje zapisu (ryc. 2).

Konsultujący pacjenta endokrynolog rozpoznał hipertyreozę w przebiegu choroby Graves-Basedowa. Do leczenia dołączono tiamazol 2 razy $20 \mathrm{mg} /$ dobę, stosowany dotychczas nebiwolol zamieniono na propranolol 3 razy $40 \mathrm{mg} /$ /dobę. Pacjentowi przedstawiono opcje leczenia nadczynności tarczycy w przebiegu choroby Graves-Basedowa:

- kontynuację leczenia tiamazolem pod ścisła kontrola parametrów morfologii krwi i endokrynologa;

- strumektomię i leczenie suplementacyjne analogiem lewotyroksyny;

- terapię jodem radioaktywnym.

Pacjent w chwili wypisania ze szpitala wybrał opcje leczenia zachowawczego. Wypisano go po 6 dniach hospitalizacji w dobrym stanie ogólnym, z zaleceniem kontynuacji leczenia przeciwzapalnego, tyreostatycznego (z zaleceniem zmniejszenia dawki tiamazolu pod kontrolą endokrynologa po uzyskaniu spadku stężenia fT3 o 50\%) i kontroli echokardiograficznej w trybie ambulatoryjnym oraz ścisłej kontroli w poradni endokrynologicznej.

\section{Omówienie}

\section{Wpływ tarczycy na serce}

Zarówno T4, jak i T3 to hormon syntezowany przez gruczoł tarczowy w odpowiedzi na stymulację przez hormon przysadkowy TSH. Tarczyca pierwotnie wydziela T4, która następnie ulega konwersji przez 5'-dejodynazę do T3 w wątrobie, nerkach i mięśniach szkieletowych. Zależność funkcji serca od hormonów tarczycy opiera się głównie na osoczowej T3, ponieważ aktywność 5'-dejodynazy w kardiomiocytach jest nieznaczna. Trójjodotyronina działa przez związanie się z receptorem jądrowym (TR, thyroid-hormone receptors). Białka tego receptora pośrednicza w indukcji transkrypcji przez związanie się z odpowiednimi genami strukturalnymi i regulatorowymi. Hormony tarczycy mają także pozagenowy wpływ na miocyty serca i naczynia systemowe przez wpływ na błonowe kanały jonowe dla sodu, potasu, wapnia, wpływ na syntezę tlenku azotu (NO) i liczne wewnątrzkomórkowe szlaki sygnalizacyjne w miocytach serca i komórkach mięśni gładkich naczyń. Razem mechanizmy genowe i pozagenowe działania T3 wpływaja na regulacje funkcji serca i hemodynamike układu sercowo-naczyniowego [1, 2]. 
Tabela 1. Wybrane parametry laboratoryjne

\begin{tabular}{|c|c|c|c|c|c|}
\hline Parametr & Zakres referencyjny & $\begin{array}{c}\text { Wartość } \\
\text { przy przyjęciu } \\
\text { (wyniki badań } \\
\text { z izby przyjęć) }\end{array}$ & $\begin{array}{l}\text { Kontrola w klinice } \\
\text { kardiologif } \\
\text { w dniu następnym }\end{array}$ & $\begin{array}{l}\text { Kontrola } \\
\text { w klinice } \\
\text { kardiologii } \\
\text { po } 3 \text { dniach }\end{array}$ & $\begin{array}{c}\text { Kontrola } \\
\text { w klinice } \\
\text { kardiologii } \\
\text { w dniu wypisu }\end{array}$ \\
\hline Liczba WBC $\left[10^{3} / \mu \mathrm{l}\right]$ & $4,0-11,0$ & 9,60 & 7,10 & & 7,10 \\
\hline Liczba NEUT $\left[10^{3} / \mu l\right]$ & & & 4,23 & & 4,89 \\
\hline Stężenie $\mathrm{Hb}$ [g/dl] & $14,00-18,00$ & 13,95 & 12,89 & 13,96 & 13,19 \\
\hline Odsetek HCT (\%) & $40,00-54,00$ & 42 & 38,9 & 41,4 & 39,9 \\
\hline $\operatorname{MCV}[f l]$ & $80-96$ & 88,00 & 88,00 & & 87,00 \\
\hline Stężenie fibrynogenu [mg/dl] & $200-400$ & 409 & & & \\
\hline Stężenie troponiny I [ng/ml] & $0,000-0,056$ & 0,011 & 0,000 & & \\
\hline Stężenie CK-MB [ng/ml] & $0,0-3,6$ & 0,1 & 0,0 & & \\
\hline Stężenie CRP [mg/l] & $0-10$ & 6,8 & 77,4 & 10,4 & \\
\hline Stężenie NT-proBNP [pg/ml] & $<125$ & & 167 & & \\
\hline Stężenie TSH [ujm./I] & $0,270-4,200$ & & & $<0,005$ & 0,006 \\
\hline Stężenie fT3 [pmol/l] & $3,1-6,8$ & & & 32,13 & 25,23 \\
\hline Stężenie fT4 [pmol/l] & $12,0-22,0$ & & & $>100$ & 84,61 \\
\hline Miano ATG [jm./ml] & $<115,0$ & & & & 47,1 \\
\hline Miano ATPO [jm./ml] & $<34$ & & & & 161,2 \\
\hline Miano anty-TSHr [jm./I] & $<1,75$ & & & & 14,20 \\
\hline
\end{tabular}

WBC (white blood cells) - krwinki białe; NEUT - neutrofile; Hb - hemoglobina; HCT (hematocrit) - hematokryt; MCV (mean corpuscular volume) - średnia objętość krwinki; CK-MB (creatine kinase MB subunit) - frakcja sercowa kinazy kreatynowej; CRP (C-reactive protein) - białko C-reaktywne; NT-proBNP (N-terminal pro B-type natriuretic peptide) - N-końcowy fragment propeptydu natriuretycznego typu B; TSH (thyrotropin-stimulating hormone) - hormon tyreotropowy; fT3 (free triiodothyronine) - wolna trójjodotyronina; fT4 (free thyroxine) - wolna tyroksyna; ATG (anti-thyroglobulin antibodies) - przeciwciała przeciwko tyreoglobulinie; ATPO (anti-thyroid peroxidase antibodies) - przeciwciała przeciwko peroksydazie tarczycowej; anty-TSHr (TSH receptor antibodies) - przeciwciała przeciwko receptorowi dla TSH

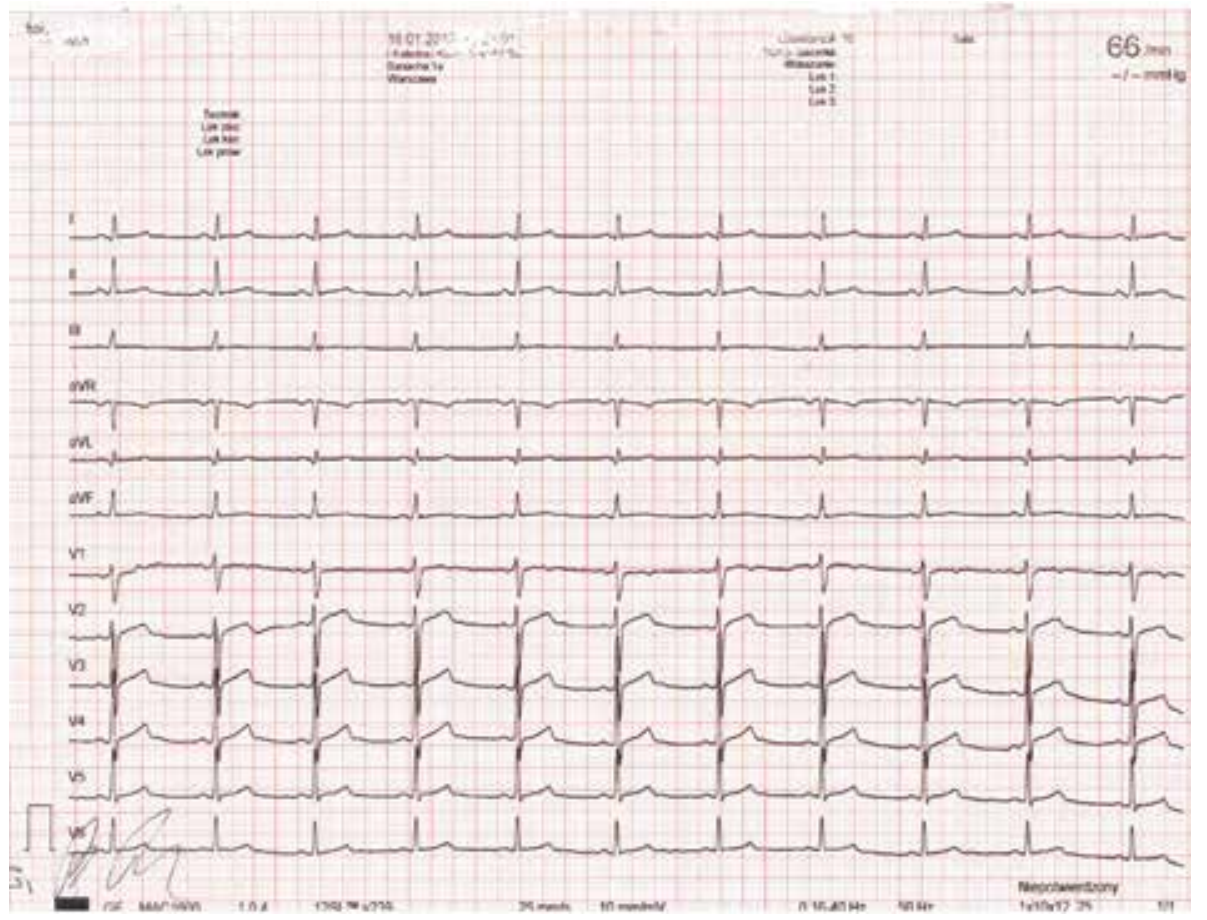

Rycina 2. Zapis elektrokardiograficzny pacjenta przy wypisie. Normalizacja zapisu 
Objawy ze strony układu sercowo-naczyniowego są jednymi z najczęstszych i najistotniejszych zarówno w niedoczynności, jak i nadczynności tarczycy. Negatywny wpływ dysfunkcji tarczycy na układ sercowo-naczyniowy objawia się zmianami w zakresie: rzutu serca, kurczliwości, BP, oporu naczyniowego, rytmu serca. Przywrócenie prawidłowej funkcji tarczycy często wiąże się z wycofaniem zaburzeń hemodynamiki serca. Zwiększona produkcja hormonów tarczycy skutkuje: kołataniami serca, tachykardią spoczynkową, obniżoną tolerancją wysiłku, dusznością wysiłkową, a także napadami migotania przedsionków. W rzadkich przypadkach pacjenci mogą prezentować ból w klatce piersiowej i zmiany w zapisie EKG sugerujące niedokrwienie mięśnia sercowego.

\section{Ostre zapalenie osierdzia jako manifestacja choroby Graves-Basedowa}

Ostre zapalenie osierdzia może się rozwinąć na podłożu wielu chorób zapalnych. W licznych przypadkach etiologia choroby pozostaje nieznana. Może wystąpić jako pierwsza manifestacja chorób autoimmunologicznych, takich jak toczeń układowy [3]. Jest częste w przypadku niedoczynności tarczycy, ale raportowano także przypadki ostrego, często nawracającego zapalenia osierdzia u chorych ze zdiagnozowaną chorobą Graves-Basedowa [4, 5]. Przypuszcza się, że w patogenezie zapalenia osierdzia, podobnie jak w innych powikłaniach choroby Graves-Basedowa (oftalmopatia, obrzęk przedgoleniowy), biorą udział nacieki limfocytarne.

\section{Diagnostyka}

Do typowych dla ostrego zapalenia osierdzia objawów należą: ostry ból w klatce piersiowej, nasilający się przy ruchach oddechowych i zmianie pozycji ciała, słyszalne tarcie osierdzia, zmiany w zapisie EKG (rozlane uniesienie odcinka ST i/lub obniżenie odcinka PQ), stwierdzany w badaniu echokardiograficznym wysięk w osierdziu, z reguły łagodny. Inne objawy mogą być związane z chorobą zasadniczą, w przebiegu której doszło do zapalenia osierdzia. W badaniach laboratoryjnych zasadniczo stwierdza się pod-

\section{Zapalenie osierdzia?}

(badanie przedmiotowe, EKG, RTG klatki piersiowej, echokardiografia, oznaczenia CRP i troponiny)

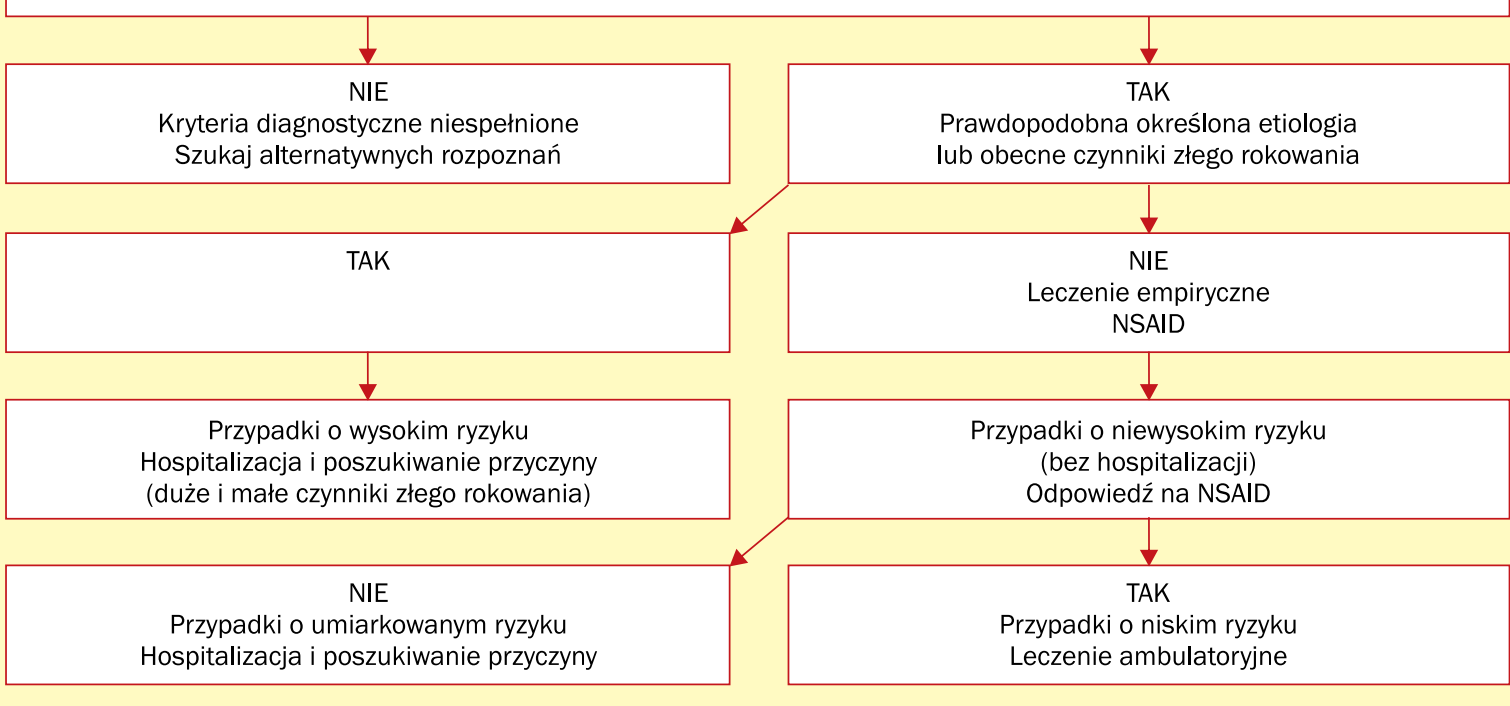

Czynniki złego rokowania

Duże:

- gorączka $>38^{\circ} \mathrm{C}$

- podostry początek

- duży wysięk w osierdziu

- tamponada serca

- brak odpowiedzi na leczenie ASA lub NSAID po przynajmniej tygodniu leczenia
Małe:

- współistniejące zapalenie mięśnia sercowego

- immunosupresja

- przebyty uraz

- terapia doustnym antykoagulantem

Rycina 3. Algorytm postępowania diagnostyczno-terapeutycznego w ostrym zapaleniu osierdzia (na podstawie [3]); ASA (acetylosalicylic acid) - kwas acetylosalicylowy; CRP (C-reactive protein) - białko C-reaktywne; EKG - badanie elektrokardiograficzne; NSAID (non-steroidal anti-inflammatory drugs) - niesteroidowe leki przeciwzapalne; RTG - badanie radiologiczne 
wyższone stężenie białka C-reaktywnego (CRP, C-reactive protein), przyspieszony odczyn Biernackiego (OB), często leukocytozę. Parametry te służą również do monitorowania aktywności procesu zapalnego i skuteczności leczenia.

W badaniu radiologicznym (RTG) klatki piersiowej zazwyczaj nie stwierdza się istotnych nieprawidłowości. Jedynie w przypadku dużego wysięku w osierdziu może być zwiększony wskaźnik sercowo-płucny. Kluczowym badaniem jest echokardiografia. Pozwala ona zidentyfikować na przykład pogrubiałe blaszki osierdzia, obecność płynu w worku osierdziowym czy cechy tamponady, a także zaburzenia kurczliwości w przypadku objęcia procesem zapalnym miokardium. Ilość płynu w worku osierdziowym ocenia się w echokardiografii 2-wymiarowej, obrazując końcowo-rozkurczowy wymiar bezechowej przestrzeni między blaszką ścienną i trzewną osierdzia. Wysięk ocenia się jako mały (< $10 \mathrm{~mm})$, umiarkowany $(10-20 \mathrm{~mm}$ ) lub duży (> $20 \mathrm{~mm}$ ). Inne badania obrazowe serca, takie jak tomografia komputerowa lub rezonans magnetyczny, mają mniejsze zastosowanie w przypadku ostrego, niepowikłanego zapalenia osierdzia. Bardziej przydatne są w ocenie jego następstw (zwapnienia w osierdziu czy wysięku w osierdziu u pacjentów z etiologią nowotworową).

Diagnostyka choroby Graves-Basedowa opiera się głównie na badaniach laboratoryjnych. Typowe są niskie lub nieoznaczalne stężenie TSH oraz podwyższone stężenie wolnych hormonów i podwyższone miano anty-TSHr. Wyniki badania USG najczęściej ujawniają powiększoną tarczycę o hipoechogenicznym miąższu.

\section{Leczenie}

Leczenie ostrego zapalenie osierdzia jest przede wszystkim objawowe. Zaleca się unikanie wysiłków fizycznych do ustą- pienia objawów i normalizacji stężenia CRP. W farmakoterapii stosuje się przede wszystkim kwas acetylosalicylowy (ASA, acidum acetylsalicylicum) lub inne niesteroidowe leki przeciwzapalne (NSAID, non-steroidal anti-inflammatory drugs), względnie kolchicynę jako lek dodatkowy w celu intensyfikacji terapii, ale także by zapobiegać nawrotom. Steroidy są zalecane jako leki drugiego rzutu w przypadku przeciwwskazań bądź niepowodzenia terapii aspiryną, NSAIDs czy kolchicyną lub gdy etiologia zapalenia osierdzia nie jest zapalna, a także gdy istnieją specjalne wskazania, na przykład choroba autoimmunologiczna [4]. Z reguły choroba ustępuje po leczeniu i nie nawraca po wyrównaniu funkcji tarczycy.

Na rycinie 3 przedstawiono algorytm diagnostyczno-terapeutyczny w ostrym zapaleniu osierdzia, a także duże i małe czynniki złego rokowania (wystąpienia powikłań w postaci tamponady serca, nawrotów czy konstrykcji).

\section{Podsumowanie}

Zapalenie osierdzia ma najczęściej przyczynę zapalną. Może rozwinąć się na podłożu chorób nowotworowych, a także autoimmunologicznych i często bywa ich pierwszym objawem. W przypadku chorób tarczycy najczęściej dotyczy pacjentów z hipotyreozą. Opisano także przypadki zapalenia osierdzia w przebiegu hipertyreozy u chorych z rozpoznaną chorobą Graves-Basedowa i dlatego w diagnostyce różnicowej zapalenia osierdzia zawsze należy brać tę jednostkę chorobową pod uwagę.

\section{Konflikt interesów}

Autorka deklaruje brak konfliktu interesów.

\section{Abstract}

The aetiology of acute pericarditis is often thought to be autoimmune. Cardiovascular complications may concern patients with thyroid diseases. Signs and symptoms such as: congestive heart failure, atrial tachyarrhythmias, atrio-ventricular conduction disturbances, mitral valve dysfunction due to thyroid diseases are well known to the clinicians. Pericarditis is a rare manifestation of thyroid dysfunction. It mostly affects patients with hypothyroidism. Very rarely it may be a cardiac manifestation of Graves' disease.

Key words: pericarditis, thyrotoxicosis

Folia Cardiologica 2016; 11, 2: 162-166

\section{Piśmiennictwo}

1. Klein I., Danzi S. Thyroid disease and the heart. Circulation 2007; 116: 1725-1735.

2. Bahn R.S., Burch H.B., Cooper D.S. i wsp. Hyerthyroidism and other causes of thyrotoxicosis: management guidelines of the American Thyroid Association and American Association of Clinical Endocrinologists. Endocr. Pract. 2011; 17: 456-520.

3. Adler Y., Charron P., Imazio M. i wsp. 2015 ESC Guidelines for the diagnosis and management of pericardial diseases: the Task Force for the Diagnosis and Management of Pericardial Diseases of the European Society of Cardiology (ESC)Endorsed by: The European Association for Cardio-Thoracic Surgery (EACTS). Eur. Heart J. 2015; 36: 2921-2964.

4. Koo E.H., Kim S.M. Park S.M. i wsp. Acute recurrent pericarditis accompanied by Graves' disease. Korean Circ. J. 2012; 42: 419-422.

5. Clarke N.R., Banning A.P., Gwilt D.J., Scott A.R. Pericardial disease associated with Graves' thyrotoxicosis. QJM 2002; 95: 188-189. 